\title{
Szövegértés és irodalomértés a magyarórán - egy Kosztolányi-vers példáján
}

Valószínúleg minden tanulási folyamatban megkerülhetetlen szerepet játszanak személyes motivumok. Jó régész, biológus vagy informatikus is abból lesz, aki szenvedélyesen érdeklódik a tárgya iránt, és nem üres ismeretek vagy pusztán haszonelvüen alkalmazandó készségek halmazának tekinti a megtanulandókat. Nem nehéz belátni, hogy az irodalom esetében a személyesnek és a szakmainak a viszonya a legtöbb egyéb tárgynál is szorosabb és összetettebb. Az irodalomtanítás egyik legfontosabb teendóje ezért mindig annak a közvetítésnek a kidolgozása, amely az egyéni élmény és az elsajátítható tudás között nyit dialógust.

gy érdeklődő középiskolás nemrég azt a kérdést tette föl nekem, hogy az irodalom „objektív” vagy „szubjektív” dolog-e. A kérdés valódi naivitásánál fogva lényegi dilemmát tár föl, amely a modern irodalomértés egyik gyakran meghaladottnak vélt, de sokszor inkább elfelejtett vagy elfojtott problémája is. A diák naiv kérdésének tanári megfelelője ez lehet: miként tudom biztosítani a személyes és a szakszerü, a szubjektívan átélhető és a fogalmilag megragadható, az emotív vagy akár fiziológiai és az intellektuális mozzanatok egyensúlyát? Mindennapos tapasztalat, hogy ezek az ellentétek leginkább akkor kerülnek szem elé, amikor valami nem müködik; amikor az oktatási folyamatban valamilyen aránytalanság áll be, és feltünik a hasadás aközött, amit az oktatás tudásként közvetít és aközött, ami személyesen átélhető.

Ha ezt a közvetítést tekintjük fő feladatnak, akkor nem nehéz belátni, hogy melyek azok a kerülendő végletek, amelyek biztosan nem tudnak eleget tenni a kitüzött követelményeknek. Az irodalmat másodkézből átadandó történeti ismeretek halmazaként kezelő gyakorlatot, amelyben az életrajz, a korrajz és a tankönyvi értelmezés egészében helyettesítheti a diák saját olvasatát, szakértők évtizedek óta ostorozzák (ld. pl. Arató, 2004), ám az iskolai hétköznapokban mégis rémisztő gyakorisággal köszön vissza. Az ezzel szinte merőben ellentétes elvekből kiinduló „élményközpontú irodalomtanítás” gyakorlata viszont a szubjektíven megélt összetevőt hangsúlyozza, ám nem mindig világos, hogy ez miként köthető össze az irodalomolvasáshoz szorosan kapcsolódó intellektuális készségek fejlesztésével, az irodalom kritikai és értelmező hagyományának közvetítésével (Füzfa, 1998). Az élményközpontúságból kiinduló pedagógia szemére vethető - mint egy német értekező, Karlheinz Fingerhut teszi -, hogy az irodalomról való beszéd kiszolgáltatása a jelenkori befogadó személyes benyomásainak elzárhatja a magához az irodalomhoz vezetö hozzáférést azáltal, hogy fölöslegesnek tünteti föl az

* A publikáció az MTA Bolyai Ösztöndíj támogatásával készült. 
irodalomról szóló kritikai, filológiai, történeti diskurzust, amivel például a régebbi, nehezebb, bonyolultabb müvek megértését is rendkívül megnehezíti. „Ha az irodalmat úgy 'mentjük meg' a szubjektív olvasás számára, hogy elválasztjuk jelentésétől és történeti szituáltságától, ezzel félreismerjük az irodalmi és a tudományos diskurzus közötti kulturális összjátékot. Társadalmunkban az utóbbi teremti meg és dolgozza ki az előbbihez való hozzáférést." (Fingerhut, 2002, 151. o.)

Az alábbiakban amellett szeretnék érvelni egy kiragadott irodalmi példa alapján, hogy az értelmezés gyakorlata (amely a humán tudományokban maga is számos átértelmezés és kritika tárgya volt az elmúlt évtizedekben) alkalmasnak látszik a fönti közvetítésre, tehát nemcsak hasznos, hanem nélkülözhetetlen összetevője egy olyan irodalomtanítási gyakorlatnak, amely igyekszik szem előtt tartani saját tárgyának alapvető természetét, és a diákokat nem kényszeríti passzív adatfeldolgozásra, de mégis igyekszik a lehetö legmélyebben bevezetni őket az irodalmi diskurzus bonyodalmaiba.

A kötelező iskolai műértelmező dolgozatnak akkor is el kell készülnie, ha a diák nem képes élményszerüen befogadni az értelmezendő művet. Több mint valószínü azonban, hogy nagyobb eséllyel válik jó müértelmezővé az, aki nem csak iskolai kényszerből fog neki irodalmi müvek olvasásának és értelmezésének, hanem rendszeresen foglalkozik olvasással és írással, netán ismerőseivel is beszélget irodalomról és kapcsolódó tárgyterületekről. Az iskolai műértelmezésben éppen az a nehézség, hogy a formalizált feladatok gyakran szinte lehetetlenné teszik a személyes megértés átvitelét az iskolai teljesítménybe; a tanár csak közvetve, a feladatmegoldás színvonala alapján ítélheti meg a diák befogadói kultúráját. Alighanem a sokszor balszerencsés formalizálás (amit azonban az oktatásban szinte lehetetlen elkerülni) okozza, hogy sokan ellentétként élik meg a müélmény és az értelmezés kettősségét. Egy amerikai középiskolai tanár saját megfigyelései szerint az iskolai olvasásértési feladatokon roszszul teljesítő diákok között nem csak olyanok vannak, akik teljességgel idegenkednek az olvasástól, hanem olyanok is, akik hobbiból falják a könyveket, de nem képesek ezt
Vischer Bruns egyik fö állítása az, hogy a modern irodalomelmélet és a rá épüló oktatási gyakorlat hajlamos élesen szembeállitani ezt a két befogadási módot, és a másodikat, a reflektáló-kritikai olvasást elönyben részesiteni. Ráadásul neves irodalomtudósok abból a feltételezésból indulnak ki, hogy az elsố (az élményszerú, átéló, a szövegbe belemerüló) olvasásmód

minden olvasó természetes képessége, míg a kritikai távlatot az oktatás feladata kifejleszteni.

Bruns részint éppen a fenti oktatási tapasztalat alapján állítja, hogy ez a szembeállítás torzító. Azon tanulók számára, akik rendszeresen olvasnak, a reflektálás épp olyan természetes tevékenység, mint a beleélés, mig az olvasástól általában idegenkedó tanulóknál éppen a beleélés képessége hiányzik. A tanulmány megfontolandó gyakorlati következetése az, hogy a közoktatásnak nagyobb hangsúlyt kell fektetnie az elmerüló-beleéló (vagyis: az élmény-

szerü) olvasás képességének kifejlesztésére, még mielótt túlzottan korán kritikai-értelmezó munkára kényszeriti a diákokat. 
a szenvedélyüket összekapcsolni az iskolai keretekhez szabott formális „szövegértési” feladatokkal (idézi: Vischer Bruns, 2011, 45. o.). Az iskolai értelmezés és a privát müélmény számukra feszültségben áll.

Pedig számos érv szól amellett, hogy az élmény és a megértés az olvasás során nem állítható szembe egymással. Ha most eltekintünk a nonszensz költészet és a hangköltészet extrém példáitól, nyilvánvaló, hogy egy szöveg szavait, mondatait értenem kell ahhoz, hogy a mű kiválthassa bennem legelemibb „fiziológiai” hatását. Ennél is komplexebb összefüggésről van szó, ha nem egyszerüen a (szószerinti) megértés, hanem a kifejtett, megfogalmazott értelmezés és a müélmény viszonyáról beszélünk. A fönt említett amerikai iskolai tapasztalatot értelmező tanulmányban Christina Vischer Bruns kétféle olvasásmódot különít el: az egyiket elmerülő ('immersive'), a másikat gondolkodó ('reflective') olvasásnak nevezi. Az elsőhöz a képzeleti beleélés, az érzelmi és hangulati ráhangolódás, a szövegnek való engedés mozzanatai kapcsolódnak, míg a másikra éppen a távolságtartás, az elemző, kritikai munka a jellemző. Az első tehát inkább passzív és jóindulatú, a másik pedig tevékeny, intellektuális és gyanakvó: a megkülönböztetés nagyjában-egészében megfelel az élmény és az értelmezés közötti korábban tett különbségnek.

Vischer Bruns egyik fó állítása az, hogy a modern irodalomelmélet és a rá épülő oktatási gyakorlat hajlamos élesen szembeállítani ezt a két befogadási módot, és a másodikat, a reflektáló-kritikai olvasást előnyben részesíteni. Ráadásul neves irodalomtudósok abból a feltételezésből indulnak ki, hogy az első (az élményszerü, átélő, a szövegbe belemerülö) olvasásmód minden olvasó természetes képessége, míg a kritikai távlatot az oktatás feladata kifejleszteni. Bruns részint éppen a fenti oktatási tapasztalat alapján állítja, hogy ez a szembeállítás torzító. Azon tanulók számára, akik rendszeresen olvasnak, a reflektálás épp olyan természetes tevékenység, mint a beleélés, míg az olvasástól általában idegenkedő tanulóknál éppen a beleélés képessége hiányzik. A tanulmány megfontolandó gyakorlati következetése az, hogy a közoktatásnak nagyobb hangsúlyt kell fektetnie az elmerülő-beleélő (vagyis: az élményszerü) olvasás képességének kifejlesztésére, még mielött túlzottan korán kritikai-értelmező munkára kényszeríti a diákokat. Noha a beleélés „az öntudat elvesztésének vagy csökkenésének tapasztalatával jár” (Vischer Bruns, 2011, 64. o.), ez a tapasztalat mégis elkerülhetetlen ahhoz, hogy képessé váljunk szövegekkel való elmélyült foglalkozásra. Vischer Bruns a pszichológus Winnicott-tól kölcsönvett fogalommal az irodalmi müvet mint ,átmeneti tárgyat” írja le, amely a személyiség és a világ közötti kapcsolódási pontként müködhet, így mind a világ megértésében, mind az önmegértésben hasznos lehet.

Ennek az érvnek az ellenpárja az a megfigyelés, hogy a tudatos, reflexív, kritikai olvasás hozzájárulhat a müélvezet elmélyítéséhez is, akár úgy, hogy korábban élvezett müveket még összetettebb, rétegzettebb formában tesz hozzáférhetővé az olvasó számára, akár úgy, hogy új, a korábbiaknál nehezebb és bonyolultabb művek befogadására is képessé teszi. A kritikai olvasás „fejleszti” a beleélő olvasást, míg a beleélés alapozza meg a kritikai olvasás szükségességét (Vischer Bruns, 2011, 78. o.). Vischer Bruns következtetései szerint tehát - ha az olvasási képességek fejlesztésére törekszünk - nincs értelme az értelem és az élmény merev szembeállításának.

E vizsgálatok is arra mutatnak, hogy az „élményszerü” irodalmi befogadás soha nem pusztán passzív, lenyügözött csodálata a müalkotásnak. A hatékony irodalomtanítási stratégiák egyik döntő kérdése ezért az, hogy miként lehet kiváltani a diák személyes részvételét oly módon, hogy az egyszersmind a megértést is elősegítse. A cselekvésorientált és drámapedagógiai technikák jelentőségét leginkább ebben lehet látni: személyes, akár testileg átélhető módot kínálnak a műalkotás világába való belépésre, ami viszont - megfelelö további közvetítéssel - a kritikai távlat megteremtésének előfeltétele.

A rendelkezésre álló terjedelem csak arra elég, hogy egyetlen költészeti példán mutassam be, tapasztalatom szerint hogyan müködhet a személyes átélésnek és a közössé, 
fogalmivá tehető értelmezésnek ez a (persze feszültségektől nem mentes) kölcsönössége. Példám egy nagyon jól ismert, a középiskolákban gyakran tanított vers, Kosztolányi Dezső Boldog, szomorú dala. A vers Nemes Nagy Ágnes (2004) szerint „nem »nehéz« vers”; például azért, mert olyan „emberi alapérzést ábrázol, amelyet mindnyájan ismerünk, vagy ismerni fogunk”. Ez a „fogunk” persze a tanárnak már nehézséget okozhat, hiszen kamasz tanítványai még biztosan nem saját tapasztalatként rendelkeznek a beérkezésnek és a „határtalan meghatározódásának” (Nemes Nagy, 2004) azzal az élményével, amely a versben a költő-utód szerint megjelenik.

Itteni mutatványomban azonban nem is elsősorban a versben megjelenő létélmény megoszthatósága mellett kívánok érvelni, hanem éppen amellett, hogy a vers feldolgozásának folyamata tehető élményszerüvé oly módon, hogy az a szövegben megfogalmazódó pszichológiai helyzetet is új megvilágításba helyezi - és ezáltal megérteti velünk, hogy a versben közismertnek vélt élethelyzet sem a pszichológia nyelvére könnyen lefordítható módon jelenik meg.

Az irodalmi szöveg átélhető megjelenítésének legfontosabb médiuma az emberi hang. A hatékony és gyors, információkereső szövegértéshez elengedhetetlen a néma olvasás - és ennek a képességnek az irodalmár is nap mint nap hasznát veszi, sőt olyan irodalmi formák mint a regény elképzelhetetlenek a néma olvasás modern kultúrája nélkül. A költői szöveg (és persze a müvészi próza) ,eminens” státusza (Gadamer) azonban részint annak köszönhetö, hogy nem oldódik föl az informatív megértés néma folyamában, hanem rászorul az emberi hang általi ismételt megszólaltatásra.

A cselekvésorientált tanításmódszertan technikái közül itt tehát egy rendkívül alapvetőt és hagyományosat emelek ki: ha arra biztatjuk tanítványainkat, hogy saját hangjukon szólaltassák meg az irodalmi múveket, ezzel mindjárt az átélésre is lehetőséget adunk (hiszen a saját hangomat kölcsönzöm a szövegnek), és megértési problémákat is előtérbe állíthatok. Különösen akkor, ha megfontoljuk a kiváló magyar- és drámatanár, Eck Júlia (2000, 43. o.) azon javaslatát, hogy az irodalmi szöveget ne is csak egy, hanem akár több hangnemben is próbáljuk megeleveníteni. A Kosztolányi-vers erre szinte felszólít minket, hiszen a címében mindjárt két hangnemi javaslatot is tesz: Boldog, szomorú dal.

Cserhalmi Zsuzsa $(2001,29$. o.) az irodalomtanításról szóló fontos könyvében joggal óv attól, hogy a vers közös órai feldolgozása során a cím szavai közötti logikai kapcsolatra kérdezzünk rá absztrakt módon. Az efféle kérdés sem nem motivál, sem továbbvezető utat nem kínál a diszkusszió számára. Ellenben ha a szöveg partitúrájának megszólaltatására biztatjuk diákjainkat, annak számos elönye lehet. Különösen akkor, ha a feladat mindjárt gondolkodásra is serkent: pl. „Elő tudod-e adni a verset egészében boldog, vagy egészében szomorú versként?” „Mely részeket tudod 'boldogan', melyeket 'szomorúan' mondani?"

Minden valamirevaló olvasó felismeri, hogy a vers nemcsak címében, hanem „hoszszanti irányban” is kettéoszlik. A „De néha megállok az éjen...” sor egyértelmü törést jelent a szerkezetben, és ettől elsőre az a benyomásunk keletkezhet, hogy a címben jelzett kettősség a vers egészére kivetül, a szöveget egy „,boldog” és egy „,szomorú” részre osztva. A vers hangos felolvasásakor vagy szavalásakor kézenfekvő megoldás, hogy ennél a sornál a versmondó megáll, lassítja a tempót, és hangszínváltozással is jelzi a törést. Hasonló történik a vers legismertebb, a Kaláka együttes általi megzenésítésében is.

Érdemes azonban eljátszani egy kicsit az interpretáció ezen lehetőségeivel: a vers címéből akár az is következhetne, hogy a szöveget kétféle módon is elő lehet adni. Próbáljuk meg tehát az egész verset „,boldogan” és „,szomorúan” elmondani! Tanítványaimmal végzett kísérleteim alapján igazolva látom, amit magából a versszövegből is erősen sejteni lehet: az egész szövegre kiterjedő „boldog” szavalat sokkal nagyobb, sőt lehetetlen kihívásnak látszik, míg az egész verset ,szomorúan” mondani sokkal könnyebb még a szöveg első felét is. Ez természetesen elsősorban a teljes szöveg ismeretében igaz: 
a vers zárlata mintegy „visszamenőleg” rányomja bélyegét a korábban elhangzottakra, és innen nézve a lírai én tulajdonairól szóló mondatok is ironikus távlatba kerülhetnek. Ennek a kísérletnek a tanulságai mindenekelőtt abban rejlenek, hogy segíthetnek felismerni azokat az alakzatokat, amelyek a vers első felében árnyalják a beérkezett, anyagi biztonságban élő, sikeres müvész magáról adott képét. Mindenekelőtt a „Szívem minek is szomorítsam?” kétértéküségét, a „Tárcám van igaz szinezüstből” túlzását (nem csak 'ezüst', és nem is csak 'színezüst', de 'igaz' színezüst), valamint az akár zavaróan ható szóismétléseket emelem ki. A feladat látható tanulsága az, hogy felfigyelünk a szöveg apró jelzéseire, amelyekkel felépíti, ám egyszersmind bonyolulttá is teszi a „,boldog-szomorú” ellentétet - pl. a már a „De” előtt megszaporodó, alliteráló „,szomorú” jelzősorozat révén.

A következtetés negatív (és ez nagyon fontos): az bizonyosodott be, hogy a szöveget sem „hosszában”, sem „széltében” nem tudjuk a boldog-szomorú ellentét alapján megosztani - sem az elsőre nyilvánvalónak látszó tagolás, sem pedig az olvasatok palimpszeszt-szerü egymásra másolása nem müködik a versnél. Erre a következtetésre - ha nem is ebben a megfogalmazásban - a diákok maguk juthatnak el akkor, ha lehetőséget kapnak eljátszani a szöveg megszólaltatási lehetőségeivel. A tulajdonképpeni értelmezés pedig akkor kezdődhet, amikor már ráismertünk a szöveg felépítésében rejlő meghökkentő - mert elözetesen adott sémákhoz nem illeszkedő - vonásokra.

Az élményszerüség ebben az esetben megértésélményként fogható föl; a verset megszólaltatni próbáló diák szembesül azzal, hogy ebben a „nem nehéz” és mindenki számára ismerős helyzetet megjelenítő versben mégis olyan nehézségek vannak, amelyek a vers konkrét nyelvi megvalósulása és a hozzá társítható értelem (mondjuk pszichológiai tartalom) feszültségéből adódnak. Ezek a nehézségek ráadásul nem korlátozódnak a vers első felére. A második szakaszban például feltünhet, hogy a „De...”-vel kezdődő nyolcsoros mondat már hosszúságánál fogva is megállásra, tagolásra késztet, és akár többféleképpen is dönthetünk arról, hogyan tagoljuk a mondatot. Hogy milyen jelentőség tulajdonítható ennek a többértelmüségnek, azt nem szükséges a középiskolások számára rögzíteni, és itt sincs hely a kifejtésére (részletesebb értelmezésemet ld.: Molnár, 2015, megjelenés alatt). Az azonban valószínúsíthető, hogy felhívja a figyelmet a mondat bonyolultságára, a benne foglalt képek egymáshoz való viszonyára. Akár újabb drámajáték helyszíne is lehet ez a versmondat, amennyiben a diákokat arra biztatjuk, hogy készítsenek illusztrációt vagy állóképet a szövegben megjelenített testhelyzetekhez - ez esetben arra lehetünk figyelmesek (ezt a megfigyelést Cserhalmi Zsuzsának köszönöm), hogy a három kép egy álló, egy kuporgó és egy fekvő testhelyzetet hoz egymás mellé.

Ennek a mondatnak a részletesebb vizsgálata sokféle nehézséget hozhat felszínre. A metrika szintjén az egyébként következetes anapesztikus lüktetés kétszeri „lelassítására" lehetünk figyelmesek, a képi síkon a három testhelyzetnek megfelelö motívumok egymáshoz való viszonya tehető kérdésessé (melyik sík szó szerinti, melyik metaforikus, melyik magyarázza melyiket?), de még a legelemibb szintaktikai szinten is kétértelmüséggel találkozhatunk. Ezekkel a problémákkal a tanuló saját „testélményén” keresztül kapcsolódhat össze akkor, ha az órán lehetőséget kap, hogy eljátssza és elmondja a verset.

Ha akár több alternatív felolvasással próbálkozunk, és biztatjuk diákjainkat a lehetséges különbségek okainak feltárására, a nyolcsoros mondat szintaktikai összetettsége felszínre fog kerülni (különösen olyan osztályban, ahol az anyanyelvtanítás feladatait sem hanyagoljuk el). A bonyodalomnak az egyik tárgyilag megragadható oka az, hogy az „úgy” szó érthető kötőszóként, de mutatószóként is:

vagy

$$
\text { „megállok, [és] úgy ásom a kincset” }
$$

„úgy ásom a kincset, mint lázbeteg”. 
Az első olvasat szerint az első és a második sík mellérendelő viszonyban áll (legalábbis ez a rekonstruált mondat következményes mellérendelö típusú), tehát a vers mondattanilag nem jelöli a szó szerintiből a figurálisra történő váltást. A másik olvasatban viszont az 'úgy' mutató névmásként előrevetíti a 'mint' kötőszót, és így kerekíti ki a jelölt hasonlatot. Ebben az esetben kevés kétségünk lehet afelől, hogy hasonlatról van szó, tehát az alakzat létrehoz egy megkettőződést a szó szerinti és az átvitt (figurális) sík között. Igen ám, de a második olvasat nem feltétlenül zárja ki az elsőt, hiszen az egész mondat így kétféleképpen tagolható, és a két szintaktikai olvasatban más lesz a hasonlított. Ezért is tulajdoníthatunk még nagyobb jelentőséget a mondat hosszának: a vesszők megengedik a kétféle tagolást, így a kétféle hangoztatást is. Ha korábban a hangos felolvasás hangnemi lehetőségeit mérlegeltük, ezúttal mondattani és logikai eltéréseket is láthatunk az eltérö interpretációk között! Lássuk, hogyan központozhatnánk másként a szöveget a kétféle olvasat szerint:

\author{
De néha megállok az éjen, \\ gyötrődve, halálba hanyatlón, \\ úgy ásom a kincset a mélyen, \\ a kincset, a régit, a padlón. \\ Mint lázbeteg, aki föleszmél, \\ álmát hüvelyezve, zavartan, \\ kezem kotorászva keresgél, \\ hogy jaj, valaha mit akartam.
}

\author{
De néha megállok az éjen, \\ gyötrődve, halálba hanyatlón. \\ Úgy ásom a kincset a mélyen, \\ a kincset, a régit, a padlón, \\ mint lázbeteg, aki föleszmél, \\ álmát hüvelyezve, zavartan. \\ Kezem kotorászva keresgél, \\ hogy jaj, valaha mit akartam.
}

Könnyen látható a két olvasat közötti finom, de mégis érdekfeszítő különbség: az 'úgy' eltérő olvasatai a 'kincs'-et helyezik más szintaktikai keretbe. Közös a két olvasatban, hogy a metaforikus síkra váltásnak nincsen közvetlen jele; legfeljebb a két igei tagmondat közé ékelt „halálba hanyatlón” szintagmát patetikus túlzásként olvasva figyelhetünk fel a hétköznapi életvilágtól való eltávolodásra.

Az első interpretáció szerint a beszélő úgy beszél a kincsásásról, mintha éjszakai meg-megállásának folyománya lenne. A 'mint' ez esetben a „kezem kotorászva keresgél” alliteráló igei szerkezetére utal elöre, amely - ha a két négysoros részt külön-külön is megálló mondatként olvassuk - valami új cselekvést vezet be; például elképzelhetjük, hogy a beszélő a zsebében kotorász, vagy éppen saját testét, homlokát tapogatja, „mint lázbeteg". Ez az olvasat a 'mint' szó kétértelmüségére is figyelmeztethet: nem is biztos, hogy ténylegesen kétszintű hasonlatról van szó, hanem a beszélő ténylegesen lázbetegként kotorászik és keresgél. Ez fontos lehet a későbbiek szempontjából, amennyiben a forróság képzetét társítja a beszélöhöz. Az első olvasatban tehát nincsen semmilyen egyértelmü jele annak, hogy átvitt értelmü beszéddel van dolgunk: a kincskeresés, a láz és a kotorászás mind a beszélő hétköznapi életének részét képezi.

A második olvasatban ezzel szemben a hasonlat jelöltebb, bár itt sem lehet teljesen kizárni a 'mint' másik jelentését. A három sík viszonya ez esetben világosabb: az első két sor a hétköznapi (bár éjszakai) világra utal, a középső mondat kétszintű hasonlatot alkot, amelyben a kincskeresés és a lázas álomfejtés kettős képe érzékelteti a beszélő éjszakai mentális gyötrődését. Végül az utolsó előtti sor visszavált a második síkra (kotorászás = ásás), és az utolsó sorban megint a hétköznapi, szó szerinti síkon vagyunk.

Ennek a szintaktikai kétértéküségnek a továbbgondolására itt nincs hely, azonban a vers „könnyen érthetőségével” kapcsolatos kételyeket jól jelzi. Az átélő olvasat és a megfelelö tanári kérdések arra késztetik a diákot, hogy felfigyeljen a versszöveg azon aspektusaira, amelyek nem könnyen oldódnak föl valamilyen jól kommunikálható, prózára fordítható tartalomban. Ha a vers egészében rábukkantunk ezeknek az elemeknek a jelentőségére, akkor a zárósorban rejlő paradoxon könnyebben feltárható („már nem vagyok 
otthon az égben"). Ehhez persze érdemes rákérdezni a boldogságot hordozó anyagi és szellemi értékek viszonyára, valamint rámutatni a vers böségszimbólumainak (kenyér, bor, dió, mák) lehetséges szakrális jelentéseire. Ezek után a zárósor időhatározójának különössége kézzelfogható lesz: ha az ég az üdvösség helyeként jövőre irányulást nevez meg, akkor a 'már' időhatározó legalábbis magyarázatot igényel. Ennek a magyarázatnak összhangban kell lennie a vers többi részével, ami több lehetséges (bár egyenként valószínűleg nem egészen kielégítő) értelmezést tesz lehetővé.

A kiemelendő mozzanat itt is az, hogy a diák maga próbálhassa ki az értelemadási lehetőségeket, a tanár pedig biztosítsa a körülményeket a vélemények szabad és viszonylag kockázatmentes, de áttekinthető diszkurzív szabályokon nyugvó cseréjére. Ennek a mozzanatnak a hangsúlyozása kiemelten fontos, és olyan megfontolásokat is szükségessé tesz, amelyek nem elsősorban az irodalomértelmezés, hanem sokkal inkább a tanulási folyamat tervezésének módszertanához tartoznak. Az ehhez szükséges módszertani eszközökről, technikákról a legrészletesebb ismertetést Pethőné Nagy Csilla (2005) adja.

Előadásomban nem a vers valamely értelmezése mellett vagy ellen érveltem, hanem olyan tanítási stratégia használata mellett, amely mindenekelőtt azt tüzi ki célul, hogy az irodalmi szöveg megértésélményét tegye a diák saját esztétikai tapasztalatának forrásává. A nehézség abban áll, hogy a megértési siker szolgáltatja a motivációt, ám valódi eseményjelleggel mégis a megértés megakadása bír. Az irodalom valóban irodalmi (nem pedig eszme- vagy müvelödéstörténeti) vonatkozásai leginkább a meg-nem-értés pillanataiban tárulnak elénk; azokban a pillanatokban, amikor a szöveg figurális, hangnemi, hangulati, stiláris összetevői nem adják meg magukat valamilyen fogalmi jelentésnek. Amit maradéktalanul megértünk - a szövegértés értelmében -, az nem irodalom; miközben az is nyilvánvaló, hogy az irodalmi szövegekhez való hozzáférés magas szintű szövegértési készségeket igényel. Az a tanítási stratégia tehát, amely képes élményszerüen szembesíteni a diákot a megértés és a meg-nem-értés izgalmas összjátékával, egyszerre tesz eleget a készségfejlesztésre való motiválás feladatának, és mutat rá az irodalom sajátos komplexitására. Ezzel tehát egyszerre teszi lehetővé a diák személyes bevonódását az irodalmi szövegtérbe, és szembesíti azzal, hogy élményének elmélyítéséhez és reflexiójához diszkurzív, fogalmi tudásra - poétikai, retorikai, filológiai, történeti ismeretekre van szüksége. A tárgyszerü ismeretek ugyanis az irodalomtanulásban soha nem öncélúak, hanem arra szolgálnak, hogy - amint „Az interpretáció művészetét” programként kitűző híres írás szerzője, a svájci Emil Staiger fogalmazott - „felfogjuk azt, ami megragad bennünket [begreifen, was uns ergreift]" (von Arburg, 2012, 252. o.). 


\section{Irodalomjegyzék}

Arató László (2004): „A kronológia nem szavatol az irodalomtörténet-lady biztonságáért”. Interjú Arató Lászlóval. Beszélö, 1. sz. http://beszelo.c3. hu/04/01/14arato.htm

Cserhalmi Zsuzsa (2001): Amit az irodalomtanitásról tudni kellene, Korona, Budapest.

Eck Júlia (2000): Drámajáték - a középiskolai irodalomórán. Országos Színháztörténeti Múzeum, Budapest.

Fingerhut, K. (2002): Didaktik der Literaturgeschichte. In: Bogdan, K.-M. és Korte, H. (szerk.): Grundzüge der Literaturdidaktik. DTV, München. 147-166.

Füzfa Balázs (1998): Az élményközpontú irodalomtanítás néhány lehetősége. In: Sipos Lajos (szerk.): Irodalomtanitás az ezredfordulón. Pauz-Westermann Könyvkiadó, Celldömölk.

Molnár Gábor Tamás (2015, megjelenés alatt): Költészet és interpretáció. Kosztolányi Dezső: Boldog, szomorú dal. Alföld.
Nemes Nagy Ágnes (2004): Kosztolányi Dezső: Boldog, szomorú dal. Verselemzés televízióra. In: uő: $A z$ élők mértana 1. Prózai írások. Osiris, Budapest. 319-329. http://dia.pool.pim.hu/html/muvek/ NEMESNAGY/nemesnagy00137a/nemesnagy 00160/nemesnagy00160.html

Pethőné Nagy Csilla (2005): Módszertani kézikönyv. Korona, Budapest.

Vischer Bruns, Ch.: (2011): Why Literature? The Value of Literary Reading and What it Means for Teaching. Continuum, New York.

von Arburg, H. G. (2012): Stimmung und Methode? Überlegungen zur Staiger-Heidegger-SpitzerDebatte. In: van Arburg, H. G. és Rickenbacher, S. (szerk.): Concordia Discors. Ästhetiken der Stimmung zwischen Literaturen, Künsten und Wissenschaften. Königshausen und Neumann. 245-259. 